\title{
The Public Service Quality of Library Service at the Library Unit Polytechnic State of Sriwijaya
}

\author{
Deri Darfin $^{1 *}$, Robinson ${ }^{1}$, Zulkarnaini $^{1}$, Ridwan Effendi ${ }^{1}$ \\ ${ }^{1}$ Informatic Management, State Polytechnic of Sriwijaya, Palembang, Indonesia \\ "Corresponding author. Email: deridarfin2@gmail.com
}

\begin{abstract}
Satisfaction is the level of feeling in which someone expresses the results of comparisons of the performance of products or services received and expected by that person. One unit in charge of serving all Polsri students is the Polsri Library Unit. Thus students' satisfaction need to be continually pursued with the aim that they continue to utilize the library. This means that students' satisfaction will be created if the library services received by students are at least comparable to the services provided by the library. Finding out the service quality can be done by comparing the students' perceptions toward the service that they actually have received with the service they actually expect toward the library service attributes. To create student satisfaction, the library must be able to meet the students' expectations, the problem to be solved is knowing how the Public Services Quality in the Polsri Library Unit are. The data taken in this qualitative study is about how the Public Services Quality in the Polsri Library Unit are, where data collection were be carried out to determine the extent of the public services quality that have been provided by the Polsri Library unit. Describing the description of the library service quality measured through aspects of service quality dimensions by Zeitahml, Pasuraman, and Berry was given as the result of this qualitative study. In conducting this research, the data were conducted by using the literature study and observation stages. Deeper, the implementation of this method in addition to conducting observations, interviews were also conducted directly with the head of Polsri Library Unit along with its staff and students as visitors. Researchers came directly and ask for input on the Public Services Quality in the Polsri Library Unit.
\end{abstract}

Keywords: service satisfaction, service quality, library

\section{INTRODUCTION}

Services in the scope of education are carried out by institutions of any level education (from elementary to higher education) based on the National Education Law Number 20 of 2003. Sriwijaya State Polytechnic (Polsri) is one of the higher education institutions in South Sumatra as a provider of vocational education leading, quality, innovative in science, technology, and art mandated to open postgraduate programs (Applied S2 and Applied S3) are public service providers, hereinafter referred to as organizers who are state-run institutions especially in the field of education formed under the law to carry out service activities.

Public in Polsri refers to the students. Implementation of public services in Polsri is related to services to the students. One of the units which is responsible to serve all Polsri students is the Polsri Library Unit. So, students' satisfaction needs to be continually pursued with the aim that they will continue to utilize the library. Reference [1] stated that quality is always as a changing situation where something which is considered qualified today can be considered less qualified in the future.

\section{METHOD}

In conducting the study towards the library services quality at Polsri Library Unit, the researchers used qualitative research methods to have deeper comprehension [2]. In conducting the study towards the library services quality at Polsri Library Unit, the following were the aspects that were examined by the researchers:

a. Subject Informants, the subject informants used in this research were the Polsri Library Unit Staff and 10 students as the library visitors;

b. Services and facilities, The services and facilities were observed in order to determine the extent of the public services quality that have been provided by the Polsri Library unit.

c. Library, library which is the location of the research carried out by the researchers and the subjects at certain times, was the Polsri Library Unit.

The data collection techniques used by the researchers were by conducting interviews and observations. Interviews are adjusted to the dimensions of service quality proposed by [3]. The dimensions were:

1. Dimensions of Reliability 


\section{a. Consistency in service \\ b. Trust in service}

2. Dimensions of Responsiveness

a. Officer readiness in helping services

b. The speed of the officer in service

3. Dimensions of Assurance

a. Skills of officers in service

b. Knowledge of officers in service

c. Friendliness of the officers in service

4. Dimension of Empathy

a. Ease to establish communication with customers

b. The willingness of officers to convey information in a language that is easily understood in the service

c. Willingness of officers to listen to complaints/ suggestions from customers

d. Willingness to understand customer needs

5. Dimensions of Tangible

a. Availability of office service physical facilities

b. Availability of service equipment

c. Availability of service officers

The researchers used incidental purposive sampling techniques in determining the 10 students as the library visitors as one of the subjects informants. The other subject informants in this study were 10 library staff officers at Polsri Library Unit including the Head of the Library Unit.

In order to fulfill the validity, the data in this qualitative study were done by extending the observation, doing continuous observation, analyzing negative cases, using references. As for the reliability, the researchers made systematic observations over and over in different situations. Since the concept of quality is relative which depends on one's perspective [4].

\section{RESULTS AND DISCUSSION}

The reserachers describes how the library service quality at Polsri Library Unit were measured through aspects of service quality dimensions by [3] which are divided into five aspects, including: Reliability, responsiveness, Assurance, Emphaty, and Tangible.

From the data of the results of interviews and observations of the author, the data were described as the following:

For the aspect of reliability, from the data results of interviews and observations, library staffs have done the service appropriately, quickly, and also carefully, this is seen from the answers of visitors who were satisfied with the services provided by library staff to them. Then, the library of the Sriwijaya State Polytechnic Library Unit also certainly has clear standards in carrying out its services. Some complaints occurred were the quietness consistency which were sometimes not happened since the librarians talked noisily which disturbed the students.

Regarding the aspect of responsiveness, According to students who came to Polsri Library Unit, librarians have been very responsive to students' needs, when they have difficulties in finding the references needed. Unfortunately, Polsri Library has not used technology- based services yet, this technology needed as a way of faster service in book regulation system.

For the aspect of the Assurance, Polsri Library Unit has provided timely guarantees, legality guarantees, and guarantees of cost in service, all guarantees are seen from the speed of service provided by officers, besides Polsri Library Unit has been confirmed to be legal because the library is an educational facility provided by Sriwijaya State Polytechnic, and the implementation of its officers and work mechanisms is regulated by a Director's Decree. Visitors are completely free of charge for services. Moreover, the librarians have participated in training and workshops conducted by the ministry in order to increase their skills and knowledge about library unit. On the other hand, in terms of friendliness, the result was on contrary. 8 of 10 students as the subject informants felt that the librarians staff officers were not friendly since they did not smile and sometimes used strong intonation in giving the information needed.

As for the empathy aspect, students felt their interests were prioritized, even though the unwillingness in conveying the information, listening to complaints were sometimes detected or felt by the students.

For aspects of tangibles students feel their needs are quite fulfilled. There are many facilities that can help visitors used such as reading services, educational services, provided by Polsri Library Unit. Then, Polsri Library Unit did not utilize information technology combined with supporting hardware for library circulation collections. The facilities for students to charge their laptop were hardly available which made the students were uncomfortable to spend long time in finishing their typing assignment.

\section{CONCLUSIONS}

From the results of the research conducted by the researchers through direct observation to Polsry Library Unit and after interviewing informants who are librarians officers staff and the Head of Library Unit, as well as some students regarding the library services quality at Polsri Library Unit, it can be concluded that the library services quality at Polsri Library Unit is only in quite good standard. This is seen from the fulfillment of aspects of service quality dimensions from [3]. Where library services quality at Polsri Library Unit has not fulfilled all of the aspects of Reliability, responsiveness, Assurance, Emphaty, and Tangible.

The visitors were satisfied enough and quite pleased with the services provided to them, where librarians and other library staff also mentioned that there were improvements still needed to be increased in the quality of their services to be better and more qualified. Students also do not need to waste a lot of time queuing up at library service desks, borrowing and repayment transaction data accuracy is not maintained better yet, and students are not invited to get to know the latest technology in getting library services. Nevertheless, the visitors of Polsri Library Unit are increasing which can be seen from the visitor statistics 
from month to month where visitors came not only from the internal environment in Sriwijaya State Polytechnic, but there were also from the environment outside Sriwijaya State Polytechnic who wanted to know about library management and services in the Sriwijaya State Polytechnic Library Unit. therefore, from the results of this research, the service quality of Polsri Library Unit must be improved eventually. Specifically in terms of tangible dimension improvement

As for maintaining the good quality of the Sriwijaya State Polytechnic Library Unit, it is necessary to create and establish the innovation initiative by making improvements such as having software performance system and its maintenance so that it has an always good response time. Then, maintenance is carried out to all facilities provided by the library, both devices and nondigital objects, such as books, library collections, and other facilities, as well as librarians friendliness. In addition, a review of the Operational System Procedures to improve service mechanisms is even better needed, and evaluate the level of visit and loan repayment transactions that occur to calculate the number of facilities both in terms of technology and library collections available whether it is still not necessarily needed or should be available. The friendliness and politeness of employees and discipline must always be maintained so that students who come can be attracted to come back to Polsri Library Unit. Furthermore, hopefully the services provided with a new improvement make the existing library within the scope of the Sriwijaya State Polytechnic can be stronger in building the relationship between the librarian and the students as the users.

\section{REFERENCES}

[1] Tjandra, W. Riawan, dkk. 2005, Peningkatan Kapasitas Pemerintah Daerah Dalam Pelayanan Publik, Pembaruan, Yogyakarta

[2] Miles, B.B., dan A.M. Huberman, 1992, Analisa Data Kualitatif, UI Press Jakarta

[3] Parasuraman, A., V. A. Zeithaml, dan L.L. Berry, 1998, SERVQUAL: A Multiple-Item Scale for Measuring Consumer Perceptions of Service Quality, Journal of Retailing, Vol. 64, No. 1.University of Miami.

[4] Lupiyodi, Rambat dan A. Hamdani, 2006. Manajemen Pemasaran Jasa, edisi 2. Jakarta: Salemba Empat. 